\title{
Typification of some names in Eucalyptus (Myrtaceae), Part 2
}

\author{
A.R. Bean \\ Queensland Herbarium, Brisbane Botanic Gardens, Mt Coot-tha Road, Toowong, Queensland \\ 4066, Australia. \\ Email: tony.bean@derm.qld.gov.au
}

\begin{abstract}
Eleven names in Eucalyptus (Myrtaceae) are here typified, and the typification is clarified or corrected for a further three names. The names dealt with in this paper include E. tessellaris var. dallachiana, E. brownii, E. cambageana, E. cloeziana, E. dawsonii, E. intertexta, E. malacoxylon, E. melanophloia, E. morrisii, E. nova-anglica, E. raveretiana, E. rudderi, E. thozetiana and E. viridis. The species involved are all indigenous to Queensland or New South Wales. A discussion of relevant type specimens is provided, together with other nomenclatural notes.
\end{abstract}

\section{Introduction}

There remain significant numbers of accepted Eucalyptus species names that have never been formally typified. The first paper in this series (Bean 2009) dealt with the typification of 15 current names in Eucalyptus. This paper deals with a further 14 names, one of which is now referable to Corymbia K.D.Hill \& L.A.S.Johnson. Of these, 11 are typified, while for a further three names the typification is clarified or corrected. Nomenclatural information offered by Brooker et al. (1984), Chippendale (1988), Hill (2002-04) and Slee et al. (2006) is discussed, especially where it differs from the view expressed here.

The species treated herein are all indigenous to Queensland or New South Wales, and are arranged alphabetically by currently accepted name.

\section{Typification}

Corymbia dallachiana (Benth.) K.D.Hill \& L.A.S.Johnson, Telopea 6: 451 (1995);

Eucalyptus tessellaris var. dallachiana Benth., Fl. Austral. 3: 251 (1867).

Type citation: "Queensland, Bowman; Rockhampton, Dallachy”. Lectotype (Blake 1953, p. 223): "Dallachy 171, from Rockhampton (MEL)" (lecto MEL1611091 here designated; isolecto: MEL1611092).

Blake (1953) chose "Dallachy 171, from Rockhampton (MEL)" as the lectotype. There are two sheets at MEL with original labels in Dallachy's handwriting, each with the 
number " 171 ". On each sheet there is a separate blue label in Mueller's handwriting stating "Eucalyptus tessellaris FvMueller var. dallachiana/ Rockhampton". In accordance with Article 9.15 (McNeill et al. 2006), Blake's initial lectotypification is here restricted to MEL1611091.

While the letter "B" written on the corner of the blue labels is confirmation that Bentham saw these sheets, the specimens were cited by Bentham in the protologue and are original material regardless of whether he saw them or not (McNeill et al. 2006, Article 9.2, Note 2).

Dallachy's handwriting is difficult to decipher, but the locality appears to be "Mt Archer", a mountain close to Rockhampton. In writing that is more legible he stated "had to cut down the tree/ I was sorry to do it".

Hill and Johnson (1995) chose a specimen at K as the lectotype. They cited the following "Dallachy 109 (lecto: K; isolecto: MEL)". Slee et al. (2006) also accepted this specimen as the lectotype. The number "109" appears on the label of the specimen at K, written by a person unknown, but certainly not by Dallachy. The origin and meaning of this number is obscure, and none of the sheets at MEL bears it (but there is another Dallachy specimen from Rockhampton, collected 5 January 1866, that lacks any number - MEL 707570). In any event Hill and Johnson's lectotypification is not valid because S.T. Blake had earlier chosen a different gathering as the lectotype. Hill and Johnson (loc. cit.) did not give any reason for not accepting Blake's choice, nor did they acknowledge it. The $\mathrm{K}$ specimen is undated. As all sheets at MEL and $\mathrm{K}$ bear similar (flowering) material, it is difficult to know whether the Kew specimen is from the 1863 gathering, the 1866 gathering, or perhaps a third gathering. Therefore, it would be unwise to designate the $\mathrm{K}$ specimen as an isolectotype.

Eucalyptus brownii Maiden \& Cambage, J. \& Proc. Roy. Soc. New South Wales 47: 215 (1913).

Type citation: "Type from Reid River near Townsville. (N. Daley, Sept. and Dec., 1912.)". Lectotype (here designated): Queensland: Reid River, via Townsville, N. Daley 8, December 1912 (NSW303042; isolecto BM (specimen on left-hand side), BRI AQ09642, NSW303043).

Specimens from both of the cited gatherings are present at NSW. One of the two sheets with the collecting number ' 8 ' from the December 1912 gathering is here chosen as the lectotype. It has pressed unmounted branchlets bearing adult leaves and mature fruits, and is in accord with the protologue. Fruiting specimens at BM and BRI have the same label details as the lectotype, and can be considered part of the same gathering.

Eucalyptus cambageana Maiden, J. \& Proc. Roy. Soc. New South Wales 47: 91 (1913

Lectotype (here designated): Queensland: Mirtna Station, [south of] Charters Towers, Z. Clark s.n., December 1912 (NSW332953; isolecto NSW332954).

The protologue states “Type from Mirtna Station, Charters Towers, Queensland (Miss Zara Clark, January and December 1912)". There are specimens from each of these gatherings at NSW, and they are in accord with the protologue. The December 1912 gathering is more complete. It comprises one sheet of pressed unmounted branchlets bearing adult leaves, mature fruits and immature buds, and a second sheet of pressed 
unmounted branchlets bearing juvenile leaves. The sheet with fertile material (NSW332953) is here designated as lectotype.

Eucalyptus cloeziana F. Muell., Fragm. 11: 44 (1878).

Type citation: "In montibus orariis ad Rockingham-Bay; Dallachy." Lectotype (Chippendale (1988, p. 122): Queensland: Rockingham Bay, J. Dallachy s.n., 22 December 1867 (MEL73642; isolecto K, MEL73641, NSW).

There are two sheets at MEL that have been identified by Mueller as E. cloeziana and collected by Dallachy. One sheet (MEL73642) has an original Dallachy label which reads "Coast Range/ 22 December 1867/ This tree has almost lost its foliage; it has large bunches of white fragrant flowers/ The tree is a small one about 30 feet high/ Bark rough and black/ wood brown". The other sheet (MEL73641) lacks a Dallachy label and is undated.

There are also specimens at K and NSW for which the labels state "Rockingham Bay, J. Dallachy". All four specimens bear leafy twigs and clustered inflorescences with open flowers, and it is reasonable to assume that they are part of the same gathering.

Chippendale (1988) cited “T: Rockingham Bay, Qld, 22 Dec. 1867, J. Dallachy s.n.; holo: MEL; iso: K, NSW". In so doing, Chippendale has specified the dated sheet at MEL. Under Article 9.8 of the International Code of Botanical Nomenclature (McNeill et al. 2006), his reference to 'holotype' is corrected to 'lectotype'.

Eucalyptus dawsonii R.T.Baker, Proc. Linn. Soc. New South Wales 24: 295 (1899).

Type citation: "Hab. - Ridges on the watershed of the Goulburn River, (R.T.B.) across the main "Divide" at Cassilis and north-west to Pillaga (Prof. Warren)." Lectotype (here designated): New South Wales: ranges on the right and left banks of Bylong Creek, Goulburn River, R.T. Baker s.n., November 1892 (NSW19159; isolecto BRI AQ110079, K, NSW326010).

There are no extant collections that have locality data exactly matching the protologue. However there are three sheets at NSW that: (1). have plant material matching the description in the protologue; (2). were collected by R.T. Baker; (3). mention the Goulburn River or 'Bylong', a town in the catchment of the Goulburn River; and (4). were annotated by Baker as Eucalyptus dawsonii. These sheets belong to two separate gatherings, with the dates of collection being Nov 1892 and 18 Oct 1898. Maiden (1920) stated "Bylong, 32 miles from Rylstone (R.T. Baker). The type". There are two gatherings that match this statement.

Slee et al. (2006) gave Baker's 1898 specimen at NSW as the lectotype, citing Maiden as the lectotypifying author. The citation by Slee et al. (2006) does not constitute a prior lectotypification, because electronic publication is not effective under Article 29 (McNeill et al. 2006). The 1892 gathering is preferred here as it is far superior in quality to the 1898 gathering and because there are specimens from it also at K and BRI. The lectotype comprises pressed unmounted branchlets displaying adult leaves, mature buds, open flowers and fruits.

Eucalyptus intertexta R.T.Baker, Proc. Linn. Soc. New South Wales 25: 308 (1900).

Lectotype (here designated): New South Wales: Nyngan, W. Baeuerlen s.n., November 1899 (NSW330009). 
The protologue cites a number of localities for the species, with some collector names included: "Dubbo to the Darling River ('Gum'; W. Baeuerlen); Nymagee, Condobolin ('Coolabah'); Mt. Hope ('Yellow Jacket' and 'Gum'); Cobar ('Coolabah Gum'); Drysdale ('Coolabah'); Bobadah, 30 miles E of Nymagee,.... For these localities I am indebted to Mr R.H. Cambage...”

The date of publication for E. intertexta is 25 September 1900 (Chapman 1991). There are just three extant specimens at NSW (where R.T. Baker's herbarium now resides) that were collected prior to September 1900 and correspond to the localities and collectors cited in the protologue. One is a good quality fruiting specimen from Nyngan, collected by Baeuerlen in November 1899; another is a sterile specimen from Drysdale, July 1899, collected by Cambage; and the last is a poor quality fruiting specimen collected by Baeuerlen in March 1900 from Girilambone (Baeuerlen 2475).

Brooker et. al. (1984) cited the type as follows: “Type: Includes Nyngan West, New South Wales, 1900, W. Baeuerlen." This is not a prior lectotypification. The word "includes" shows that these authors were not choosing a single element as a type, but rather were listing one of the specimens that they considered a syntype. There is no specimen with these details at NSW, but there is such a specimen at K. I have chosen as lectotype the Nyngan specimen at NSW collected by Baeuerlen in November 1899. Nyngan lies within the area encompassed by the "Dubbo to the Darling River" statement in the protologue, and the specimen has a label bearing Baker's handwriting. It comprises a single sheet of pressed unmounted branchlets bearing adult leaves and mature fruits.

Eucalyptus malacoxylon Blakely, Key Eucalypts 145 (1934).Basionym: E. stuartiana var. grossa Maiden, Crit. Revis. Eucalyptus 3: 69 (1917).

Lectotype (here designated): New South Wales: Hanging Rock, Nundle, J.H. Maiden \& J.L. Boorman s.n., June 1906 (NSW41833; isolecto A, CANB, K).

The protologue states “... the following notes were made by me in front of it [the tree?] in June, 1906, when it was collected by Mr J.L. Boorman and myself. It occurs, say, 2 miles from Hanging Rock (on the Nundle Road)...”.

There are two gatherings that might be considered in the choice of a lectotype. Chippendale (1988) cited them as follows: "Hanging Rock, near Nundle, N.S.W., June 1906, J.H. Maiden \& J.L. Boorman s.n.; syn: FRI, K, NSW; Hanging Rock, near Nundle, N.S.W., June 1904, J.L. Boorman s.n. syn: BM, NSW.”

The lectotype designated here has a collection date that closely matches the protologue. It comprises copious pressed unmounted branchlets. If mounted separately the branchlets would probably occupy three or four standard sized herbarium sheets. The branchlets bear juvenile leaves, adult leaves with attached buds (almost mature), adult leaves with attached mature fruits, and there are some separate mature fruits (in a packet).

Eucalyptus melanophloia F.Muell., J. Proc. Linn. Soc., Bot. 3: 93 (1859).

Type citation: "A tractu montano Newcastle Range usque ad sinum Moreton Bay Eucalypto crebra abunde adsociata, solum sterilibus indicans". Lectotype (here designated): Queensland: Dawson River, F. Mueller s.n., undated [1856] (K, material on upper half of sheet). 
Chippendale (1988) cited two syntypes for E. melanophloia, both at K, namely "Mitchell 485" and "Moore s.n.". This citation was accepted by Hill (2002-04) and Slee et al. (2006). However, I do not accept that these specimens are syntypes. A footnote at the start of Mueller's paper (Mueller 1859) stated "the accompanying MS. has been compared with the specimens from Dr. Mueller and A. Cunningham in the Hookerian Herbarium, by Mr. Allan Black, Curator of the Herbarium, who has added some habitats and notes". Throughout Mueller's paper, such additions are discernable by being in a separate paragraph and enclosed in brackets. For E. melanophloia, the specimen citations inserted into the text by Mr Black are "(N. Holl. Sub-Trop., Mitchell. Moreton Bay, Moore. Sydney Woods, Paris Exhib. No. 66, in hb. Hook.)”. These citations are not part of the protologue of E. melanophloia F.Muell., cannot have any bearing on the typification of the name and do not constitute mention of a specimen or gathering, according to Article 37.3, Note 2 (McNeill et al. 2006)..

Mueller did not cite any specimens for E. melanophloia, and so the lectotype must be chosen from the original material. The protologue refers to Mueller's travels during the North Australian Expedition (1855-56), led by A.C. Gregory. MEL does not hold any specimens of E. melanophloia collected by Mueller, but there are Mueller specimens from four gatherings at K, mounted on two sheets. The localities associated with these gatherings are 'Gilbert River', 'Dawson River', 'Burnett River' and 'Eastern subtropical Australia'. The material collected from Dawson River is of good quality (and is from a region the expedition passed through). It comprises pressed and mounted branchlets; two bearing leaves only and three bearing mature fruits only. This material is in accord with the protologue and is here designated as the lectotype. There is no sheet number currently available for this specimen. The label (written in Mueller's hand) includes the notation "Silver leaved Ironbark tree Colon" [of the colonists].

Eucalyptus morrisii R.T.Baker, Proc. Linn. Soc. New South Wales 25: 312 (1900)

Lectotype (here designated): New South Wales: Girilambone, W. Baeuerlen s.n., December 1899 (NSW310761).

The protologue states that the species occurs "near Girilambone, on stony or rocky hills, thence on hills across country to Cobar; also near Coolabah, where it occurs on more or less level and less stony ground (W. Bauerlen)". Maiden (1917) stated "drawn from the type specimen collected by Mr. W. Baeuerlen at Girilambone". However, there are at least three gatherings made by Baeuerlen from Girilambone before the publication of the name (25 $5^{\text {th }}$ September 1900, Chapman 1991).

NSW310761 is chosen here as lectotype as it is in agreement with the protologue, is a good quality specimen and would have been available to the author. It comprises pressed unmounted branchlets bearing adult leaves, mature buds, open flowers, immature fruits and mature fruits. In addition, there are some loose mature fruits in a packet.

Eucalyptus nova-anglica H.Deane \& Maiden, Proc. Linn. Soc. New South Wales 24: 616 (1900); E. cinerea var. nova-anglica (H.Deane \& Maiden) Maiden, Crit. revis. Eucalyptus 3: 9 (1914).

Lectotype (Chippendale 1988, p. 371): New South Wales: Moona Plains, Walcha, A.R. Crawford 1, September 1898 (NSW316904). 
The protologue states that "It is common over the greater portion of New England. It occurs on the summit of Ben Lomond". This does not constitute mention of a single specimen or gathering (McNeill et al. 2006: Article 37.3, Note 2). Maiden (1914) stated "The type specimen, Moona Plains, Walcha, N.S.W. (A.R. Crawford.)". However, there are Crawford specimens from two gatherings (Feb 1899 and Sep 1898) that match this citation. To overcome the nomenclatural problem of two syntypes, Chippendale (1988) cited the type as "T: Moona Plains, Walcha, N.S.W., Sept. 1898, A.R. Crawford s.n.; lecto: NSW, fide J.H.Maiden, Crit. Revis. Eucalyptus 3: 22 (1914).”

Chippendale (loc. cit.) has effectively lectotypified the name by citing Crawford's September 1898 specimen at NSW, even though this specimen is labelled as Crawford No. 1. The collection made by Crawford in February 1899 is without a collection number.

Eucalyptus raveretiana F.Muell., Fragm. 10: 99 (1877).

Type citation: "In vallibus udis silvaticis et secus ripas umbrosas Australiae orientalis capricornicae; O'Shanesy”. Lectotype (here designated): Queensland. Rockhampton, P.A. O'Shanesy 1390, 17 March 1873 (MEL1517650).

There are specimens of this taxon collected by Bowman, Thozet, O'Shanesy and Fitzalan held at MEL. As Mueller cited “O'Shanesy" as the collector, the lectotype must be chosen from amongst his collections. Chippendale (1988) listed the type as "near Rockhampton, Qld, P. O’Shanesy s.n.; holo: MEL; iso: K”. However there are three specimens (from three different gatherings) at MEL that were collected by O'Shanesy from the Rockhampton area. Chippendale's statement cannot be readily matched with any one of these gatherings. Each of the three specimens has an original label specifying its place of collection (Rockhampton; Gracemere near Rockhampton; Gracemere), collection date (a different date for each), and collection number.

In the protologue, Mueller described mature buds, stamens, anthers and stigma, and stated "semina matura me nondum visa". The MEL specimen from O'Shanesy's 1873 collection [MEL1517650] bears a single mounted branchlet with adult leaves, buds, open flowers and immature undehisced fruits, and hence is a very good match for the protologue. It is here selected as the lectotype.

Eucalyptus rudderi Maiden, Proc. Linn. Soc. New South Wales 29: 779 (1905).

Lectotype (Chippendale 1988, p. 412): New South Wales: Cundletown, A. Rudder s.n., July 1885 (NSW135705).

The protologue cites the following collections "Cundletown, near Taree (A. Rudder)", "in the counties of Gloucester and Macquarie", and "parish of Bohnock, a few miles from Taree. It appears to favour stony ridges (J. Hardiman)”. There are specimens at NSW corresponding to each of the cited localities in the protologue, each from a separate gathering, namely (1). a collection by Rudder from Cundletown; (2). a collection by the District Forester Taree (probably J.J. Hardiman), from county Gloucester, Oct 1904; and (3). a collection cited as by J.J. Hardiman from Parish Bohnock, County Gloucester, 18 August 1904.

Maiden (1911) cited several extra localities, but he did not select any specimen as a type either in the text (pp. 118 and 119) or in the caption for the illustration (p. 132). 
Chippendale (1988) cited the type as follows: "Cundletown, near Taree, NSW, Jul 1885, A. Rudder s.n.; lecto: NSW, fide N. Hall and M.I.H. Brooker, Forest Tree Ser. No. 193 (1977)". However, it is incorrect to infer that Hall and Brooker (1977) chose a lectotype. They wrote that "...Maiden does not specifically state what the type material was. L.A.S. Johnson has chosen as a lectotype a specimen from Cundletown, near Taree." Unfortunately, Johnson never formally chose a lectotype for E. rudderi in any of his subsequent publications, but he did annotate the Cundletown sheet with the words "should be taken as the lectotype".

Chippendale's citation of this specimen is here regarded as formally satisfying the requirements of the code ( $\mathrm{McNeill}$ et al. 2006). The lectotype is a specimen of poor quality comprising two small leafy branchlets and a packet containing some flowers and very immature fruits. Nevertheless it is identifiable as the taxon now known as E. rudderi.

Eucalyptus thozetiana (Maiden) R.T.Baker, Proc. Linn. Soc. New South Wales 31: 305 (1906); E. calycogona var. thozetiana Maiden, Crit. Revis. Eucalyptus 1: 87 (1903).

Type citation: "I have examined specimens from (a) Expedition Range, Queensland, (M. Thozet, in herb. Melb.); (b) 'Eucalyptus from the Mackenzie River, Queensland. It sheds all the bark except that on the butt of the trunk' (W. Woolls, who labelled it E. tesselaris); (c) and (d) Warrego and Flinders River, Queensland (F.M. Bailey). The fruits are small, narrow, and sub-cylindrical, but perhaps not perfectly ripe." Lectotype (Brooker et al. 1984, p. 506): "Expedition Range (southeast of Emerald), Queensland, A. Thozet”; (lecto MEL 231745 (here designated); isolecto NSW333172).

E. gracilis var. thozetii F.M.Bailey, Queensland Fl. 2: 615 (1900), nomen nudum.

Mueller (1879) made an obscure reference to the species to which the name E. thozetiana is now applied. In his treatment of Eucalyptus gracilis, he wrote "either as a variety, or perhaps even as a species can be distinguished from E. gracilis, an Eucalyptus gathered by the lamented late Monsieur A. Thozet in his last botanical journey to Expedition Range." Although Mueller did annotate some specimens at MEL with the name "E. thozetiana", he never effectively published the name.

Maiden (1903) was the first to validly publish the epithet "thozetiana" in the combination E. calycogona var. thozetiana. He cited four gatherings:

Baker (1906) provided a detailed description and discussion of the species for which he adopted the name E. thozetiana. He attributed the name to Mueller, based on the statement quoted above. This has given rise to the commonly quoted authorship of "F.Muell. ex R.T.Baker". Baker acknowledged the "var. thozetiana" erected by Maiden (1903), and merely raised it to species rank, so that the authorship of E. thozetiana should be “(F.Muell. ex Maiden) R.T.Baker” or "(Maiden) R.T.Baker”.

Brooker et al. (1984) stated "Type: Expedition Range (southeast of Emerald), Queensland, A. Thozet." While there is only one gathering that fits this statement, specimens from it exist at both NSW and MEL. In accordance with Article 9.15 (McNeill et al. 2006), the initial lectotypification of Brooker et al. (1984) is here narrowed to the MEL specimen. The MEL specimen has been chosen in preference to the NSW specimen because Maiden stated in the protologue that he had examined the Thozet specimen “in Herb. Melb.”. 
Eucalyptus viridis R.T.Baker, Proc. Linn. Soc. New South Wales 25: 316 (1900).

Type citation: "on the hills near Girilambone, N.S.W., thence across country to Cobar; also seven miles out from Coolabah on the Wilga Downs road (W. Baeuerlen) Lectotype (here designated): New South Wales: Girilambone, W. Baeuerlen 2535, March 1900 (NSW333684; isolecto NSW333679, NSW333681, NSW333682 \& NSW333683).

Maiden (1910), in the caption for an illustration of E. acacioides, stated "Girilambone, N.S.W. (W. Baeuerlen.) Type of E. viridis, R. T. Baker”. There are at least three gatherings that match Maiden's statement. Baeuerlen's March 1900 gathering comprises five sheets at NSW. These specimens have original labels in the handwriting of W. Baeuerlen, and would have been available to the author before publication, as the name was published on the $25^{\text {th }}$ September 1900 (Chapman 1991). The unmounted material on these sheets is of good quality with branchlets bearing leaves, mature buds, flowers and fruits. The buds and fruits are a good match for those shown in the illustration in the protologue, but no specimens have been found with misshapen leaves as portrayed in that illustration. NSW333684 has been chosen as the lectotype, with the remaining sheets being regarded as isolectotypes.

\section{Acknowledgments}

I am grateful to the Directors of the National Herbarium of Victoria (MEL) and the National Herbarium of New South Wales (NSW), for allowing access to the collections, and for assistance during my visits. These institutions have also provided images of specimens at my request; for this I am grateful. Jeremy Bruhl (Australian Botanical Liaison Officer at K, 2007-2008) and Tony Orchard (ABLO 2008-2009) kindly sent images of important collections of eucalypts; I thank the Royal Botanic Gardens Kew $(\mathrm{K})$, and the Natural History Museum London (BM) for allowing images of specimens held by them to be supplied to me. I sincerely thank Gillian Perry for her guidance and cheerful response to my numerous queries.

\section{References}

Baker RT (1906) On two species of Eucalyptus, undescribed or imperfectly known, from eastern Australia. Proceedings of the Linnean Society of New South Wales 31: 303-308.

Bean AR (2009) Typification of some names in Eucalyptus (Myrtaceae), Part 1. Telopea 12(3): 309-319

Blake ST (1953) Studies on Northern Australian species of Eucalyptus. Australian Journal of Botany 1: 185-352.

Brooker MIH, Kleinig DA \& Boland DJ (1984) Eucalyptus. Pp. 193-549 in Boland DJ (ed.), Forest Trees of Australia, $4^{\text {th }}$ edition. (Nelson: CSIRO, Melbourne)

Chapman AD (1991) Australian Plant Name Index, D-J. (Australian Biological Resources Study: Canberra)

Chippendale GM (1974) Herbarium specimens of Eucalyptus photographed in Europe. (Technical Note No. 7. Forestry and Timber Bureau: Canberra)

Chippendale GM (1988) Eucalyptus, Angophora (Myrtaceae). Flora of Australia 19. (Australian Government Publishing Service: Canberra)

Hall N \& Brooker MIH (1977) Rudder's box - Eucalyptus rudderi Maiden. Forest Tree Series No. 193. (CSIRO Division of Forest Research: Melbourne) 
Hill KD (2002-04). Eucalink, A web guide to the eucalypts. Royal Botanic Gardens, Sydney. Available at http://plantnet.rbgsyd.nsw.gov.au/PlantNet/Euc/index.html Accessed on 17 Apr 2009.

Hill KD \& Johnson LAS (1995) Systematic studies in the eucalypts 7. A revision of the bloodwoods, genus Corymbia (Myrtaceae). Telopea 6: 185-504.

Maiden JH (1903) Eucalyptus calycogona. A Critical Revision of the Genus Eucalyptus. volume 1, part 3, pp. 77-89. (Government Printer: Sydney)

Maiden JH (1910) Eucalyptus acacioides. Caption for Plate 52. A Critical Revision of the Genus Eucalyptus. volume 2, part 11, pp. 58. (Government Printer: Sydney)

Maiden JH (1911) Eucalyptus rudderi. A Critical Revision of the Genus Eucalyptus. volume 2, part 13, pp. 118-119. (Government Printer: Sydney)

Maiden JH (1917) Eucalyptus morrisii. A Critical Revision of the Genus Eucalyptus. volume 4, part 32, pp. 56-58. (Government Printer: Sydney)

Maiden JH (1920) Eucalyptus dawsonii. A Critical Revision of the Genus Eucalyptus. volume 5, part 42, pp. 56-57. (Government Printer: Sydney)

McNeill J, Barrie FR, Burdet HM, Demoulin V, Hawksworth DL, Marhold K, Nicolson DH, Prado J, Silva PC, Skog JE, Wiersema JH \& Turland NJ (2006) International Code of Botanical Nomenclature (Vienna Code). (International Association for Plant Taxonomy: A.R.G. Gantner Verlag, Ruggell, Liechtenstein)

Mueller F (1859) Monograph of the eucalypti of tropical Australia; with an arrangement for the use of colonists according to the structure of the bark. Journal and Proceedings of the Linnean Society, Botany 3: 81-101.

Mueller F (1879) Eucalyptus gracilis. Eucalyptographia, Decade 3. (John Ferres, Government Printer: Melbourne)

Slee AV, Brooker MIH, Duffy SM \& West JG (2006) Euclid, Eucalypts of Australia, Third edition (DVD-Rom). (Centre for Plant Biodiversity Research: Canberra) 